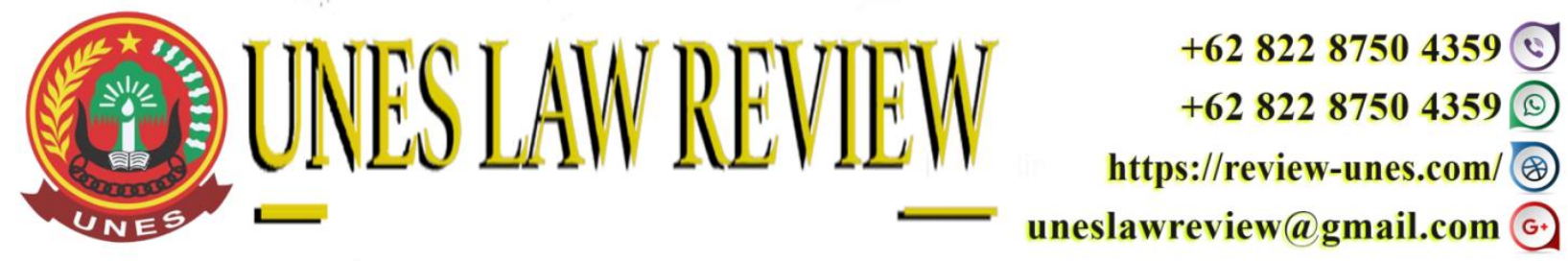

DOI: https://doi.org/10.31933/unesrev.v3i2

Diterima: 01/12/2020, Diperbaiki: 11/12/2020, Diterbitkan: 14/12/2020

\title{
KARAKTERISTIK HUKUM ISLAM PADA ZAMAN PENJAJAHAN BELANDA DAN JEPANG
}

\author{
${ }^{1)}$ Fitra Mulyawan, ${ }^{2)}$ Dora Tiara \\ 1) 2) Dosen Fakultas Hukum, Universitas Ekasakti, Padang, Indonesia \\ Email: moelyaftr@yahoo.com
}

Corresponding Author: Fitra

\section{ABSTRACT}

In the development of Indonesian National Law, the existence of Islamic law is very important, apart from being a material for the preparation of national law, Islamic law is also an inspiration and dynamist in the development of national law. In addition, the study of the history of Islamic law in Indonesia can also be used as a basis for Muslims in particular to determine the right strategy in the future in bringing and "familiarizing" this nation with Islamic law. It cannot be denied that Muslims in Indonesia are the most dominant element. At the level of the international Islamic world, Indonesian Muslims can even be called the largest Muslim community gathered within one state territorial boundary. then there are several problem identifications regarding this matter, namely how the development and characteristics of Islamic law during the Dutch and Japanese colonial times. Because of the characteristics of Islamic law in Indonesia during the Dutch colonial era, legal historians divide it into two periods: first, the period of full acceptance of Islamic law or what is commonly known as reseption in Complexu. Second, the period of acceptance of Islamic law by customary law which is commonly called the receptiveness theory. The characteristics of Islamic law in Indonesia during the Japanese colonial era, namely regarding the position of Islamic law in the national legal system during the Japanese colonial period, there was no significant change from the previous period. Only change the names of institutions that existed during the Dutch colonial period into Japanese.

Kata Kunci: Karakteristik, Hukum Islam, Zaman, Penjajahan

\section{PENDAHULUAN}

Hukum Islam baru dikenal di Indonesia setelah agama Islam disebarkan di tanah air. Ketentuan kapan Islam datang ke Indonesia tidak ada kata sepakat diantara para ahli sejarah Indonesia. Ada yang mengatakan pada abad pertama Hijriyah, ada yang mengatakan abad ketujuh Masehi, ada pula yang mengatakan abad ketujuh Hijriyah atau sekitar abad ketiga belas Masehi (Muhammad Hasan al-Aydrus, 1996:41).

Walaupun ahli sejarah berbeda pendapat tentang waktu Islam masuk ke Indonesia namun mereka sepakat bahwa hukum Islam telah diterapkan di Indonesia seutuhnya semenjak 
datangnya Islam ke Indonesia dan masyarakat menerima hukum tersebut dengan baik. Hal ini dapat terlihat pada studi para pujangga yang hidup ketika itu mengenai hukum Islam dan peranannya dalam menyelesaikan perkara-perkara yang timbul dalam masyarakat. Hasil studi dan karya ahli hukum Islam di Indonesia, kemudian dapat disebut sebagai contoh, Miratut Tullab oleh Abdul Rauf Singkel, Siratul Mustakim oleh Nuruddin al-Raniri, Sabilal Muhtadin oleh Syaikh Arsyad al-Banjari dan lain-lain, di samping studi mengenai hukum Islam yang ditulis oleh bukan orang Indonesia misalnya Muharrar karangan al-Rafi'i, Tuhfah karangan Ibn Hajar, Nihayah karangan al-Ramli dan kitab-kitab hukum mazhab Syafi'i lainnya. Setelah Belanda menjajah nusantara, perkembangan hukum Islam dikendalikan dan sesudah tahun 1927 tatkala teori reseptie mendapat landasan peraturan perundang-undangan (IS 1925, 1929) perkembangan hukum Islam dihambat di tanah air (Muhammad Daud Ali, 2004:209-210).

Karena itu, menjadi sangat menarik untuk memahami alur perjalanan sejarah hukum Islam di tengah-tengah komunitas Islam terbesar di dunia itu. Pertanyaan-pertanyaan seperti seberapa jauh pengaruh kemayoritasan kaum muslimin Indonesia itu terhadap penerapan hukum Islam di Tanah Air ? Maka dapat dijawab dengan memaparkan sejarah hukum Islam sejak komunitas muslim hadir di Indonesia. Di samping itu, kajian tentang sejarah hukum Islam di Indonesia juga dapat dijadikan sebagai salah satu pijakan bagi umat Islam secara khusus untuk menentukan strategi yang tepat di masa depan dalam mendekatkan dan "mengakrabkan" bangsa ini dengan hukum Islam. Proses sejarah hukum Islam yang diwarnai "benturan" dengan tradisi yang sebelumnya berlaku dan juga dengan kebijakan-kebijakan politik-kenegaraan, serta tindakan-tindakan yang diambil oleh para tokoh Islam Indonesia terdahulu setidaknya dapat menjadi bahan telaah penting di masa datang. Setidaknya, sejarah itu menunjukkan bahwa proses Islamisasi sebuah masyarakat bukanlah proses yang dapat selesai seketika.

Tidak dapat dipungkiri bahwa umat Islam di Indonesia adalah unsur paling mayoritas. Dalam tataran dunia Islam internasional, umat Islam Indonesia bahkan dapat disebut sebagai komunitas muslim paling besar yang berkumpul dalam satu batas teritorial kenegaraan.

Dari hal-hal yang telah diuraikan dalam latar belakang tersebut di atas maka ada beberapa pengidentifikasian masalah mengenai hal itu yaitu bagaimana perkembangan serta karakteristik Hukum Islam pada :

1. Masa Penjajahan Belanda

2. Masa Penjajahan Jepang

\section{METODE PENELITIAN}

Metode penelitian dalam studi ini adalah yuridis normatif, yaitu penelitian yang bersumber dari norma dan kaidah hukum, peraturan perundang-undangan yang berlaku, teori dan doktrin hukum, dan bahan kepustakaan yang dianggap relevan dengan topik penelitian. Sesuai dengan metode penelitian yuridis normatif, maka sumber data dalam penelitian ini berupa data sekunder dengan bahan hukum primair, sekunder dan tersier. Cara memperoleh bahan hukum dilakukan dengan penelusuran, pengumpulan kemudian dilakukan pengkajian yang berupa kepustakaan, peraturan perundang-undangan, hasil penelitian, karya ilmiah serta dokumen lainnya yang dianggap perlu. Analisis yang digunakan adalah deskriptif kualitatif, dengan cara mengolah data yang ada dan dilakukan penyajian dalam bentuk narasi. Data diuraikan, dibahas dan ditafsirkan untuk merumuskan kesimpulan dari pertanyaan studi penelitian ini (Julaiddin, 2020:138-139). 


\section{HASIL DAN PEMBAHASAN}

\section{Karakteristik Hukum Islam di Indonesia Pada Masa Penjajahan Belanda}

Eksistensi hukum Islam di Indonesia sekarang ini sesungguhnya memiliki sejarah yang sangat penting. Akar genealogisnya dapat dilihat jauh ke belakang, yaitu pada saat pertama kali Islam masuk ke Nusantara, mulai dari kerajaan Samu-dera Pasai di Aceh, kerajaan Mataram di Jawa, kerajaan Banjar di Kalimantan, dan kerajaan Islam di Makassar, serta kerajaan-kerajaan Islam di beberapa wilayah nusan-tara lainnya. Pelaksanaan dan nama dari badan pelaksana hukum Islam pada masing-masing kerajaan tersebut berbeda-beda sesuai dengan kondisi dan situasi masing-masing kerajaan (Zainal Abidin Abu Bakar, 1984:24). Misalnya di kerajaan Banjar, pada masa pemerintahan Sultan Suriansyah sudah ada mufti-mufti yang bertugas menjadi penasehat kerajaan di bidang agama Islam dan Qadli atau hakim yang bertugas menangani perkara-perkara yang berkenaan dengan hukum keluarga dan hukum perkawinan serta menangani masalah-masalah privat, terutama yang terkait dengan perkara-perkara pidana/hudud.

Kedatangan bangsa Belanda, pertama kali dipelopori oleh ekspedisi di bawah pimpinan Cornelis de Houtman tahun 1596 M. Mereka berhasil mendarat di Pelabuhan Banten dan bermaksud mengadakan kontak perniagaan dengan para saudagar pribumi.

Pada tahun 1602 di negeri Belanda berdiri suatu perhimpunan dagang untuk daerah Timur Jauh yang dikenal dengan nama De Vereenigde Oost Indische Compagnie yang disingkat dengan VOC. Dalam akta pendiriannya, yang ditetapkan oleh Staten Generaal (Badan Pemerintahan Tertinggi) tanggal 20 Maret 1602 M, kongsi dagang ini diberikan hak-hak istimewa (hak octroi), diantaranya adalah: Hak monopoli perdagangan, hak memiliki tanah, hak membentuk angkatan perang, hak mendirikan benteng pertahanan, mengumumkan perang dan damai, hak mencetak mata uang, dan hak membuat perjanjian dengan raja-raja di Jawa. Lebih lanjut, dalam pasal 35 hak octroi tersebut, VOC juga mendapat kewenangan untuk mengangkat Officieren van Justitie (Pegawai Penuntut Keadilan) untuk menjaga ketertiban umum, kepolisian dan lembaga peradilan (Supomo, 1982:9).

Dengan berbagai macam hak octroi tersebut, maka kongsi dagang VOC dengan sendirinya mempunyai dua sifat, yaitu sifat sebagai badan perniagaan dan sifat sebagai badan pemerintahan, yang memiliki kekuasaan seperti sebuah pemerintahan negara tersendiri.

Sejak saat itulah, tujuan kedatangan mereka yang pada awalnya hanya ingin melakukan kontak perniagaan dengan para saudagar pribumi berubah menjadi kolonialisasi dengan berupaya merebut kekuasaan untuk mengambil keuntungan komoditi dari bumi Nusantara yang terkenal kaya dengan berbagai macam rempah-rempah yang sangat diminati dan sangat laku di pasaran dunia.

Dalam perkembangan berikutnya, menurut Ratno Lukito, kolonialisme Belanda ini semakin meluas, tidak berhenti pada penguasaan sumber-sumber ekonomi. Setidaknya terdapat tiga misi dalam kolonialisme Belanda ini, yaitu: Pertama, menguasai sumber daya alam Nusantara yang kaya. Kedua, menghilangkan pengaruh Islam dari sebagian besar orang Indonesia dengan proyek Kristenisasi. Ketiga, Menerapkan apa yang mereka sebut dengan 
politik hukum yang sadar terhadap Indonesia. Maksudnya, Belanda ingin menata dan mengubah kehidupan hukum di Nusantara dengan hukum Belanda (Ratno Lukito, 1998:28).

Menurut Bushar Muhammad, (dalam Suparman Usman, 2001:107) penjajah Belanda sebelum datang ke Nusantara mengira bahwa Nusantara masih berupa hutan belantara, yang penuh dengan satwa, dengan penduduk yang masih primitif tanpa mempunyai aturan hukum di dalamnya. Namun yang mereka lihat kenyataannya tidak demikian. Mereka menyaksikan kenyataan bahwa di daerah yang kemudian mereka sebut sebagai Hindia-Belanda sudah ada hukum yang berlaku, yaitu hukum Islam, di samping hukum adat (adatrecht). Hukum Islam bahkan telah menjadi hukum yang ditaati oleh umat Islam di Nusantara dan sudah menjadi "hukum negara" pada kerajaan-kerajaan Islam (Busthanul Arifin, 1998:2). Kenyataan ini terlihat, sebagaimana diuraikan oleh Van Vollenhopen (dalam Utrecht, 1961:203-204) :

"Ketika tahun 1596 kapal Belanda yang pertama tiba di Nusantara, maka terdapatlah suatu negeri -yang ditinjau dari sudut hukum negara-bukan negeri yang tandus dan kosong. Negeri tersebut penuh sesak dengan lembaga tata negara dan tata usaha. adalah kekuasaan oleh dan atas suku, desa, perserikatan, republik dan kerajaan".

Selanjutnya, perkembangan kolonialisme Belanda yang sekaligus membawa agama Nasrani yang mereka anut, membuat rakyat Indonesia yang mayoritas beragama Islam melakukan perlawanan terhadap mereka, yang kebetulan pada saat itu sedang berlangsung periode kebangkitan Islam. Sehingga perlawanan antar umat Islam dengan kaum penjajah Belanda identik dengan perlawanan antar agama.

Perlawanan keras dari umat Islam membuat penjajah Belanda mengambil sikap yang cukup keras dan antisipatif terhadap setiap gerakan yang dilakukan rakyat agar tidak menghambat kepentingan-kepentingan mereka, baik perdagangan, politik, maupun agama. Mereka manganggap Islam sebagai ancaman dan perlu mendapat perhatian khusus. Almarhum H. Aqib Suminto (1986:199) menuliskan:

"Keinginan keras pemerintah Hindia Belanda untuk tetap berkuasa di Hindia-Belanda, mengharuskan mereka untuk menemukan politik Islam yang tepat, karena sebagian besar penduduk kawasan ini beragama Islam. Dalam perang menaklukkan bangsa Indonesia selama sekian lama, Belanda menemukan perlawanan keras justru dari pihak-pihak raja Islam terutama, sehingga tidak mengherankan bila kemudian Islam dipandangnya sebagai ancaman yang harus dikekang dan ditempatkan dibawah pengawasan yang ketat".

Berangkat dari perspektif ini, pemerintah Hindia-Belanda mengeluarkan berbagai kebijakan politik, termasuk kebijakan hukum, yang terkait dengan Islam dan para penganutnya. Politik hukum penjajah Belanda inilah yang selanjutnya membawa pengaruh pada perjalanan hukum Islam di Indonesia.

Selanjutnya mengenai perkembangan hukum Islam pada masa kolonial Belanda, biasanya para ahli sejarah hukum membaginya menjadi dua periode: pertama, periode penerimaan hukum Islam sepenuhnya atau yang biasa disebut reseption in Complexu, yaitu periode berlakunya hukum Islam sepenuhnya bagi orang Islam karena mereka memeluk agama Islam; kedua, periode penerimaan hukum Islam oleh hukum adat yang biasa disebut teori receptie. Teori ini 
mengandung pengertian bahwa hukum Islam itu berlaku apabila diterima atau dikehendaki oleh hukum adat (Juhaya S. Praja, 1991:10).

Teori yang pertama di kemukakan pertama kali oleh Prof. Mr. Lodewijk Willem Christian Van Den Berg (1845-1927). Namun kemudian teori ini dikecam oleh Prof. Snouck Hugronye, dan sebagai gantinya ia mengajukan teorinya yang disebut "Theori Receptie". Menurut teori ini hukum yang berlaku di Indonesia adalah hukum adat asli. Hukum Islam telah berpengaruh dalam hukum adat. Hukum Islam baru mempunyai kekuatan kalau dikehendaki dan diterima oleh hukum adat. Akibatnya, yang berlaku kemudian adalah hukum adat, bukan hukum Islam. Teori tersebut selain tidak sesuai dengan Kenya-taan hukum yang berlaku dalam masyarakat Indonesia waktu itu, ternyata teori tersebut sengaja dimunculkan untuk memecah belah masyarakat Indonesia.

Dampak dari berlakunya teori Snouck ialah menjadi berkurangnya wewenang dan kekuasaan pengadilan Agama. Jika sebelumnya pengadilan Agama mengurusi perkara-perkara sengketa antara suami dan istri, sengketa tentang waris, perkara hibah, sadaqah, waqaf, wasiat dan yang terkait dengan itu semua, maka setelah itu, khususnya di Jawa dan Madura, kekuasaan dan wewenang pengadilan Agama hanya terbatas dengan masalah penyelesaian sengketa suami istri.

Pada masa kolonial Belanda sejarah hukum Islam (Islamic legal history) di Indonesia memasuki babak baru. Ismail Sunny, membagi sejarah hukum Islam pada periode ini kedalam dua fase. Pertama, masa dimana hukum Islam diterima sepenuhnya sebagai hukum yang ada dan telah berlaku di masyarakat, dan kedua masa ketika hukum Islam baru dapat diterapkan jika dikehendaki oleh hukum adat.

Periode yang disebut pertama dipengaruhi oleh teori receptio in complexu, yaitu masa dimana hukum Islam diberlakukan secara penuh terhadap orang Islam karena mereka telah memeluk Islam. Receptio in Complexu adalah suatu teori hukum, yang digagas oleh Ledewijk Willem Christian Van Den Berg, yang berpendirian bahwa "hukum yang berlaku bagi pribumi didasarkan pada agama yang dipeluknya".

Menurut Berg: "Receptio in Complexio oleh bangsa Hindu dari hukum Hindu, oleh kaum Islam dari hukum Islam, oleh kaum Kristen dari hukum Kristen. Selama bukan sebaliknya dapat dibuktikan menurut ajaran ini, hukum pribumi ikut agamanya, karena jika mengikuti suatu agama, harus juga mengikuti hukum agama-agama itu dengan setia" (Proyek IAIN Syahid, 1981:9). Dengan teori ini, Van Den Berg telah membagi keberlakuan hukum menurut agama yang dianut. Bagi orang Islam berlaku hukum Islam, sedangkan bagi orang non-muslim berlaku hukum mereka. Pandangan Van den Berg ini menegaskan suatu kenyataan bahwa antara orang Islam dan hukum Islam tidak dapat terpisahkan, serta dari hubungan ini muncul apa yang dikenal dengan asas personalitas keislaman.

Pendapat Berg ini didasarkan oleh beberapa kenyataan ketika itu. Pertama bahwa kehidupan keagamaan merupakan ciri khas dari masyarakat Nusantara, di mana agama tidak dapat dilepaskan dari kehidupan masyarakat sehari-hari. Kedua, keyakinan dalam masingmasing agama mengikat begitu kuat, sehingga segala bentuk pranata sosial dipengaruhi olehnya. 
Ketiga, kecenderungan Van Den Berg terhadap keberlakuan hukum agama, mengisyaratkan bahwa pengaruh Eropa yang dibawa oleh kolonial Belanda tentang pemisahan antara masalah dunia dan agama tidak mendapatkan lahan yang subur pada masa itu. Kenyataan bahwa Islam merupakan agama mayoritas, telah mengarahkan Van Den Berg kepada pendapat bahwa hukum yang berlaku dalam masyarakat Indonesia adalah hukum Islam (Chtijanto, 1985:117).

Atas pengaruh teori Receptio in Complexio, pemerintah Kolonial pada masa ini mengakui hukum yang telah berlaku sejak berdirinya kerajaan-kerajaan Islam di Nusantara, seperti hukum keluarga Islam. Bahkan hukum keluarga Islam selanjutnya diakui dan diterapkan dengan bentuk peraturan Resolutie der Indische Regeering tanggal 25 Mei 1760, yang merupakan kumpulan hukum perkawinan dan hukum kewarisan Islam yang dikenal dengan compendium freijer.

Compendium Freije merupakan satu bentuk legislasi hukum Islam pada masa kolonial Belanda karena ia disusun dengan melibatkan para penghulu dan 'alim ulama. Compendium, yang merupakan realisasi dari tuntutan keadilan hukum masyarakat muslim pribumi ini, diumumkan keberlakuannya terhadap masyarakat pribumi di wilayah perbentengan Jakarta (Betawi) pada tahun 1760 (Muhammad Daud Ali, 1989:212). Meski demikian, Supomo mengkritik bahwa Compedium ini sama sekali tidak berpijak pada realita masyarakat sehari-hari dan hanya mendasarkan pada pertimbangan ulama-ulama yang cenderung "idealis".

Selain itu, keberlakuan hukum Islam yang telah berjalan sejak zaman kesultanan oleh pemerintah kolonial dikukuhkan dasar hukumnya dalam Undang-Undang Dasar Hindia-Belanda, yang dikenal dengan Regeerning Reglement (RR) tahun 1855. Dalam pasal 75 RR dinyatakan: "Oleh hakim Indonesia itu hendaklah diperlakukan undang-undang agama (godsdienstige), bahkan dalam pasal 78 ditegaskan lebih lanjut: "Dalam hal terjadi perkara perdata antara sesama orang Indonesia itu, atau dengan mereka yang dipersamakan dengan mereka maka mereka tunduk kepada putusan hakim agama atau kepala masyarakat mereka menurut undang-undang agama (godsdienstige wetten) atau ketentuan-ketentuan lama mereka" (Isma'il Sunny, 1985:7).

Eksistensi hukum Islam dalam tata hukum kolonial semakin kuat setelah dikeluarkannya Keputusan Raja Belanda (Koninkelijik Besluit) No. 19 tanggal 24 Januari 1882 yang kemudian diumumkan dalam Staatsblad tahun 1882 No. 152 tentang pembentukan Pristerraad (Pengadilan Agama).

Dari kepustakaan yang ada diperoleh catatan lain bahwa sebelum Peradilan Agama ini diresmikan pada tahun 1882, pemerintah kolonial telah mengakui keberadaan dan berjalannya Peradilan Agama pada masyarakat Islam Nusantara di antaranya adalah:

1. Pada bulan September 1808 ada satu instruksi dari pemerintah Hindia Belanda kepada para Bupati yang berbunyi: "Terhadap urusan-urusan agama orang Jawa tidak akan dilakukan gangguan-gangguan, sedangkan pemuka-pemuka agama mereka dibiarkan untuk memutuskan perkara-perkara tertentu dalam bidang perkawinan dan kewarisan dengan syarat bahwa tidak akan ada penyalahgunaan, dan banding dapat dimintakan kepada hakim banding".

2. Pada tahun 1820 melalui Stbl No. 22 Pasal 13 ditentukan bahwa bupati wajib memperhatikan soal-soal agama Islam dan untuk menjaga supaya para pemuka agama 
dapat melakukan tugas mereka sesuai dengan adat kebiasaan orang Jawa, seperti dalam soal perkawinan, pembagian pusaka, dan yang sejenis itu. Dari istilah "bupati" dalam ketentuan tersebut di atas dapat disimpulkan bahwa Peradilan Agama telah ada di seluruh pula Jawa.

3. Pada tahun 1823, melalui resolusi Gubernur Jenderal tanggal 3 Juni 1823 No. 12 diresmikan Pengadilan Agama di kota Palembang yang diketuai Pangeran Penghulu sedangkan banding dapat dimintakan kepada Sultan. Wewenang Pengadilan Agama Palembang meliputi: perkawinan, perceraian, pembagian harta, kepada siapa anak diserahkan apabila orang tua bercerai, apa hak masing-masing orang tua terhadap anak tersebut, pusaka dan wasiat, perwalian, dan perkara-perkara lainnya.

4. Pada tahun 1835, melalui Resolusi tanggal 7 Desember 1835 yang dimuat dalam Stbl 1835 No. 58, pemerintah Hindia-Belanda saat itu mengeluarkan penjelasan tentang pasal 13 Stbl 1820 No. 20 dengan isi sebagai berikut: "Apabila terjadi sengketa antara orangorang Jawa satu sama lain mengenai soal-soal perkawinan, pembagian harta dan sengketa-sengketa yang sejenis, yang harus diputus dengan hukum Islam, maka para pemuka agama memberi keputusan, tetapi gugatan untuk mendapat pembayaran yang timbul dari keputusan para pemuka agama itu harus dimajukan kepada pengadilanpengadilan biasa" (Munawir Sjadzali, 1994:43).

Pada periode berikutnya terjadi pergeseran kebijakan politik hukum pemerintah kolonial. Perubahan ini terjadi tidak lepas dari adanya perubahan peta politik di negeri Belanda sendiri, di mana parlemen Belanda dikuasai kelompok Kristen konservatif. Pada awalnya Pemerintah Hindia-Belanda ingin mengganti doktrin receptio in complexu dengan teori unifikasi, yaitu dengan menerapkan sistem hukum kontinental (sistem hukum yang digunakan di Belanda) terhadap orang Indonesia. Namun, ide tersebut mendapat penentangan keras dari para ahli hukum adat terutama Van Vollenhoven, seorang sarjana hukum adat. Menurut Vollenhoven, penerapan hukum unifikasi hanya akan memunculkan penerapan hukum yang artifisial dan tidak sesuai dengan kesadaran sosial masyarakat Indonesia.

Para ahli hukum adat Belanda, terutama setelah munculnya tokoh fenomenal seperti C. Snouck Hurgronje (1994), yang diangkat oleh pemerintah Hindia Belanda sebagai penasehat untuk urusan pribumi dan Islam, kemudian memperkenalkan teori receptie.

Gagasan teori receptie, sebagai pengganti atas teori receptio in complexu, menjadi salah satu nasehat penting Snouck dalam pengambilan kebijakan hukum kolonial. Menurut Teori Resepsi, hukum yang berlaku di Nusantara bukanlah hukum Islam, melainkan hukum adat. Ke dalam hukum adat itu terdapat pengaruh hukum Islam. Oleh karenanya, hukum Islam itu baru mempunyai kekuatan berlaku kalau sudah diterima (direcipier) sebagai hukum adat. Dengan dasar teori ini maka hukum Islam baru dapat diakui keberlakuannya jika ia dikehendaki dan diterima oleh hukum adat.

Pendapat Snouck ini selanjutnya pada tahun 1929 diberi dasar hukumnya dalam UndangUndang Dasar Hindia-Belanda yang menjadi pengganti dari RR yang disebut Wet op de Staatsinrichting van Nederland Indie, disingkat Indische Staatsregeling (IS). Dengan dasar IS 
ini keberadaan hukum Islam dicabut dari lingkungan tata hukum Hindia Belanda, sebagaimana ditegaskan dalam pasal 134 ayat (2) IS: "Dalam hal terjadi perkara perdata antara sesama orang Islam akan diselesaikan oleh hakim agama Islam apabila hukum adat mereka menghendakinya dan sejauh itu tidak ditentukan lain dengan suatu ordonansi".

Pada pertengahan tahun 1937, Pemerintah Hindia-Belanda mengumumkan pemindahan wewenang pengaturan waris kepada pengadilan negeri (landraad) lewat pemberlakuan Staatsblad 1937 No. 116. Dengan ketentuan ini maka apa yang menjadi kompetensi pengadilan agama praktis hanya di bidang perkawinan dan hal ini semakin mereduksi lingkup peradilan agama. Sehingga wewenang pengadilan agama berdasarkan ketentuan baru yang diatur dalam Pasal 2 (a) hanya meliputi:

1. Perselisihan antara suami isteri yang beragama Islam.

2. Perkara-perkara tentang nikah, talak, rujuk dan perceraian antara orang-orang beragama Islam yang memerlukan perantara hakim agama Islam.

3. Menyelenggarakan perceraian.

4. Menyatakan bahwa syarat untuk jatuhnya talak yang digantungkan (ta'lik al thalaq) telah ada.

5. Perkara mahar dan mas kawin.

6. Perkara tentang keperluan kehidupan isteri yang wajib diadakan suami (Asasriwarni, 2008:92.

Perkara-perkara di atas tidak sepenuhnya menjadi wewenang Pengadilan Agama, karena dalam perkara-perkara tersebut bila terdapat tuntutan pembayaran uang dan pemberian harta benda, maka harus diperiksa dan diputuskan oleh landraad. Kenyataan di atas yang membatasi kekuasaan Pengadilan agama terutama pencabutan hak waris, menimbulkan perasaan tidak senang dikalangan umat Islam, sehingga mereka mengadakan reaksiterhadap stbl. 1937 Nomor 116 dan memohon agar ketentuan itu dicabut kembali, karena pada tanggal 1 Januari 1938, Belanda mendirikan Hof Voor Islamietische Zaken atau Mahkamah Islam Tinggi (MIT), sebagai pengadilan tingkat banding terhadap keputusan-keputusan pengadilan Agama. Lahirnya ketentan ini bertujuan untuk menentramkan keadaan.

Kebijakan hukum kolonial Belanda di akhir masa penjajahannya, dengan mereduksi kewenangan Peradilan Agama serta memarginalkan posisi hukum Islam dalam system hukum kolonial lewat "Politik Hukum Adat", ditujukan untuk menghambat dan menghentikan meluasnya agama Islam karena agama ini mengajarkan perlawanan terhadap kolonialisme Belanda. Selain itu, politik hukum ini merupakan implementasi politik divide-at-impera (politik pecah belah) kolonial Belanda untuk melemahkan kekuatan perlawanan yang dimotori Islam dengan cara membentuk semacam lembaga hukum tandingan, yaitu dengan memelihara adat kebiasaan dan menghidupkan kembali lembaga-lembaga adat kuno yang sudah hampir lenyap. Mereka menghantam Peradilan Agama juga dikarenakan Peradilan Agama merupakan simbol kekuasaan, eksistensi dan juga bentuk legislasi hukum Islam dalam hukum negara.

Selain perubahan politik hukum kolonial, ada faktor lain yang mendorong marginalisasi hukum Islam dalam konstalasi hukum kolonial. Menurut Wasit Aulawi ada dua faktor internal 
yang sangat memprihatinkan yang ikut melemahkan posisi hukum Islam, khususnya di lembaga pengadilan agama ketika itu, yaitu aparat hukum yang tidak handal dan peraturan hukum yang tidak jelas. Padahal kedua faktor ini menjadi dua dari tiga pilar untuk tegaknya suatu tata hukum yang kokoh.

\section{Karakteristik Hukum Islam di Indonesia Pada Masa Penjajahan Jepang}

Jepang masuk ke Indonesia pada tahun 1942. Pendudukan Jepang atas Indonesia yang hanya berlangsung tiga tahun tidak memberikan perubahan yang berarti terhadap eksistensi hukum Islam dalam tata hukum nasional, begitu juga dalam karakteristik Hukum Islam di Indonesia.

Setelah Jendral Ter Poorten menyata-kan menyerah tanpa syarat kepada pang-lima militer Jepang untuk kawasan Selatan pada tanggal 8 Maret 1942, segera Pemerintah Jepang mengeluarkan berbagai peraturan. Salah satu diantaranya adalah Undang-Undang Nomor 1 Tahun 1942, yang menegaskan bahwa Pemerintah Jepang meneruskan segala kekuasaan yang sebelumnya dipegang oleh Gubernur Jenderal Hindia Belanda. Ketetapan baru ini tentu saja berimplikasi pada tetapnya posisi keberlakuan hukum Islam sebagaimana kondisi terakhirnya di masa pendudukan Belanda.

Pada tahun 1942, tepatnya pada tanggal 8 Maret, Pemerintah Militer Jepang mengeluarkan Osamu Seirei (peraturan organic bagi daerah Jawa dan Madura) yang merupakan implementasi dari Undang-undang No. 1 tahun 1942 untuk memberikan arah bagi pelaksanaan pemerintahan. Dalam salah satu pasalnya dinyatakan bahwa: "Semua badan pemerintahan dan kekuasaan, hukum dan undang-undang dari pemerintahan yang terdahulu (Pemerintah Kolonial Belanda), tetap diakui sah buat sementara waktu, asal saja tidak bertentangan dengan aturan Pemerintah Militer Jepang, yang berfungsi sebagai aturan peralihan” (R. Tresna, 1978:84-85).

Dengan dasar peraturan organik tersebut maka kewenangan dari Pengadilan Agama di masa Jepang ini tidak mengalami perubahan, selain adanya aturan yang mewajibkan perubahan nama-nama lembaga yang ada ke dalam bahasa Jepang, seperti pergantian nama Pengadilam Agama dengan nama Suuryoo Hooin dan Mahkamah Islam Tinggi diganti dengan nama Kai koyo Kooto Hooin (Daniel S. Lev, 1986:45). Sehingga nama peradilan agama di masa Belanda tidak berlaku lagi, akan tetapi, walaupun nama dan sebutan bahasa Jepang dipakai untuk nama kedudukan para pejabat dan nama kantor, namun fungsi dan wewenang pengadilan agama tetap sama seperti di zaman Belanda. Pada masa jepang ini, kedudukan peradilan agama pernah terancam, yaitu dikeluarkannya suatu peraturan oleh Sayo dan Co Keigijimushitu (Dewan Pertimbangan Agung) pada tanggal 14 april 1945 yang berbunyi:

"Urusan pengadilan agama dalam negara baru yang memisahkan urusan negara denganurusan agama sebagai pengadilan istimewa, untuk mengadili urusan seseorang yang bersangkut paut dengan agamanya cukup segala perkara diserahkan kepada pengadilan biasa yang dapat minta pertimbangan seseorang ahli agama” (Idris Ramulyo, 1992:79). 
Peraturan tersebut dikeluarkan sebagai jawaban terhadap pertanyaan yang diajukan oleh bala tentara Jepang tentang bagaiman sikap dewan terhadap penghulu dan cara mengurus kas mesjid dalam hubungannya dengan kedudukan agama dalam negara merdeka kelak.

Ada beberapa kebijakan kolonial Jepang di daerah di luar Jawa yang membawa kemajuan dan memperkuat kedudukan pengadilan agama, seperti di Aceh yang memberi kebebasan kepada ulama untuk melaksanakan ajaran agamanya. Namun, menurut Daniel S. Lev, konsesi tersebut tidak berarti apa-apa selain hanya untuk menarik dukungan ulama terhadap mereka.

Gejolak masyarakat Islam terhadap pemberlakuan Staatsblad 1937 No. 116, tentang pengalihan wewenang pengadilan agama mengadili perkara waris kepada pengadilan negeri (landraad), tidak luput dari perhatian pemerintah Jepang ini. Mereka meminta Supomo, seorang ahli hukum adat yang diangkat sebagai sanyo (istilah bagi orang-orang yang ditunjuk oleh pemerintahan Jepang sebagai penasihat), untuk membuat laporan/jawaban atas persoalanpersoalan hukum dan pemerintahan yang ditanyakan pemerintah kolonial Jepang. Dalam laporannya, Supomo menyertakan pula laporan tentang kedudukan Pengadilan Agama dan masalah waris ini. Ternyata dalam perumusan laporan, bahan, usulan dan saran dari para tokoh Islam dan para penghulu, oleh Supomo dimanipulasi sedemikian rupa, sehingga menjadi sebuah saran penentangan terhadap pemulihan wewenang peradilan agama tersebut (Taufik Abdullah, 2000). Laporan Supomo ini memang tidak ditindaklanjuti, tetapi Pemerintah kolonial Jepang memilih tetap pada status quo terhadap Staatsblad 1937 No. 116 tersebut.

Menurut Daniel S. Lev, para pemimpin Islam di masa penjajahan Jepang berusaha memperoleh kembali hak-hak juridiksi peradilan agama, namun hal ini dihambat oleh kelompok nasionalis yang dimotori oleh kelompok priyayi. Apa yang dilakukan Supomo di atas adalah salah satu bentuk usaha dari kelompok yang disebut terakhir ini.

Terkait dengan politik hukum kolonial Jepang, Abikusno Tjokrosujoso, seorang pemimpin Islam kala itu, berpendapat bahwa :

"Kolonial Jepang melihat bahwa Islam merupakan suatu kekuatan yang dapat dipergunakan. Setiap pemerintahan ingin melakukan tugasnya dengan baik, apalagi pemerintahan asing yang mempunyai tujuan-tujuan tertentu. Ia harus dapat menemukan masalah besar yang menjadi kepentingan utama dari masyarakat, yang oleh pemerintahan sebelumnya tidak pernah diperhatikan. Jepang menyadari bahwa Islam merupakan golongan paling penting dan berniat mempergunakannya. Namun Jepang kurang memahami Islam, tidak mempunyai ahli tentang Islam dan seringkali bingung menghadapi tuntutan dan sikap golongan Islam. Politik pendudukan Jepang kurang memberikan keuntungan bagi Islam. Sewaktu saya ditanya mengapa pemerintah Jepang tidak mengabulkan banyak hal yang dituntut oleh golongan Islam, terutama yang menyangkut Pengadilan Agama Islam, saya menjawab bahwa bagi pemerintah Jepang yang terpenting adalah berusaha agar segala sesuatu berjalan secara aman dan terkendali, mereka tidak mau mengambil tindakan-tindakan apapun yang dapat mengganggu ketentraman dalam negeri, terutama masalah pengadilan agama".

Dengan pemaparan Abikusno tersebut, terlihat bahwa Jepang sesungguhnya tidak melakukan upaya politik hukum apapun terhadap hukum Islam, selain menjaga agar suasana tetap kondusif dan mendukung usaha-usaha peperangan terhadap sekutu yang tengah mereka 
lakukan dan tengah menjadi konsentrasi mereka ketika itu. Oleh karena itu, mengenai posisi hukum Islam dalam system hukum nasional pada masa kolonial Jepang tidak ada perubahan yang berarti dari periode sebelumnya.

Meskipun demikian, Pemerintah Pendudukan Jepang tetap melakukan berbagai kebijakan untuk menarik simpati umat Islam di Indonesia (Bahtiar Effendy, 1998:93), di antaranya adalah:

1. Janji Panglima Militer Jepang untuk melindungi dan memajukan Islam sebagai agama mayoritas penduduk pulau Jawa.

2. Mendirikan Shumubu (Kantor Urusan Agama Islam) yang dipimpin oleh bangsa Indonesia sendiri.

3. Mengizinkan berdirinya ormas Islam, seperti Muhammadiyah dan NU.

4. Menyetujui berdirinya Majelis Syura Muslimin Indonesia (Masyumi) pada bulan oktober 1943.

5. Menyetujui berdirinya Hizbullah sebagai pasukan cadangan yang mendampingi berdirinya PETA.

6. Berupaya memenuhi desakan para tokoh Islam untuk mengembalikan kewenangan Pengadilan Agama dengan meminta seorang ahli hukum adat, Soepomo, pada bulan Januari 1944 untuk menyampaikan laporan tentang hal itu. Namun upaya ini kemudian "dimentahkan" oleh Soepomo dengan alasan kompleksitas dan menun-danya hingga Indonesia merdeka.

Dengan demikian, nyaris tidak ada perubahan berarti bagi posisi hukum Islam selama masa pendudukan Jepang di Indonesia. Namun bagaimanapun juga, masa pendudukan Jepang lebih baik dari pada Belanda dari sisi adanya pengalaman baru bagi para pemimpin Islam dalam mengatur masalah-masalah keagamaan.

\section{KESIMPULAN}

Berdasar atas pembahasan sebagaimana telah diuraikan di atas maka dapat ditarik kesimpulan sebagai berikut:

1. Karakteristik hukum Islam di Indonesia pada zaman penjajahan Belanda adalah para ahli sejarah hukum membaginya menjadi dua periode: pertama, periode penerimaan hukum Islam sepenuhnya atau yang biasa disebut reseption in Complexu, yaitu periode berlakunya hukum Islam sepenuhnya bagi orang Islam karena mereka memeluk agama Islam; kedua, periode penerimaan hukum Islam oleh hukum adat yang biasa disebut teori receptie. Teori ini mengandung pengertian bahwa hukum Islam itu berlaku apabila diterima atau dikehendaki oleh hukum adat.

2. Karakteristik hukum Islam di Indonesia pada zaman penjajahan Jepang yaitu mengenai posisi hukum Islam dalam system hukum nasional pada masa kolonial Jepang tidak ada perubahan yang berarti dari periode sebelumnya. Hanya merubah nama-nama lembaga yang ada pada masa penjajahan Belanda ke dalam bhasa Jepang. Tetapi Pemerintah Pendudukan Jepang tetap melakukan berbagai kebijakan untuk menarik simpati umat Islam di Indonesia. 


\section{DAFTAR PUSTAKA}

Ahmad Noeh dari Islamic Courts in Indonesia, Jakarta: PT. Intermasa, 1986.

Aqib Suminto, Politik Islam Hindia Belanda, Jakarta : LP3ES, 1986.

Asasriwarni, Sejarah Peradilan Islam, Padang, IAIN Press, 2008.

Bahtiar Effendy, Islam dan Negara: Transformasi Pemikiran dan Praktek Politik Islam di Indonesia, Jakarta: Paramadina, 1998

Busthanul Arifin, Budaya Hukum itu Telah Mati, Jakarta : Kongres Umat Islam, 1998.

Chtijanto, "Pengadilan Agama sebagai Wadah Perjuangan Mengisi Kemerdekaan Bangsa", dalam Kenang-kenangan Seabad Pengadilan Agama, Jakarta: Dirbinbapera Dep. Agama RI, 1985.

Daniel S. Lev, Peradilan Agama di Indonesia, Terjemah oleh Zaini Idris Ramulyo, Beberapa Masalah tentang Hukum Acara Perdata Peradilan Agama dan Hukum Perkawinan Islam, Jakarta: Ind-Hillco, 1992.

Ismail Suny, "Kedudukan Hukum Islam dalam Sistem Ketatanegaraan Indonesia" dalam Amrullah Ahmad et.al (ed.), Prospek Hukum Islam Kerangka Pembangunan Hukum Nasional di Indonesia : Sebuah Kenangan 65 Tahun Prof. Dr. H. Busthanul Arifin, SH, Jakarta: PP IKAHA, 1994.

Juhaya S. Praja, "Pengantar" dalam Eddi Rudiana Arief, Hukum Islam Di Indonesia Perkembangan dan Pembentukan, Bandung: Remaja Rosda Karya, 1991.

Julaiddin, Akses (Justice) Mendapatkan Keadilan Dalam Konstitusi Indonesia, Jurnal UNES Law Riview, Volume 2, Issue 2, Desember 2019

Muhammad Daud Ali, "Kedudukan Hukum Islam dalam Sistem Hukum Indonesia", dalam Taufik Abdullah dan Sharon Shiddique (ed.), Tradisi dan Kebangkitan Islam di Asia Tenggara, Jakarta : LP3S, 1989.

, Hukum Islam; Pengantar Ilmu Hukum dan Tata Hukum Islam di Indonesia, Jakarta: PT. Raja Grafindo Persada, 2004.

Muhammad Hasan al-Aydrus, Penyebaran Islam di Asia Tenggara, Jakarta: Lentera, 1996.

Munawir Sjadzali, "Landasan Pemikiran Politik Hukum Islam dalam Rangka Menentukan Peradilan Agama di Indonesia" dalam Hukum Islam di Indonesia: Pemikiran dan Praktek, Bandung: Remaja Rosdakarya, 1994.

Proyek IAIN Syahid, Laporan Penelitian tentang Teori Resepsi, Jakarta: Lembaga Penelitian, 1981.

R. Tresna, Peradilan Indonesia dari Abad ke-Abad, Jakarta: Pradnya Paramita, 1978.

Ramly Hutabarat, Kedudukan Hukum Islam dalam Konstitusi-Konstitusi Indonesia

Ratno Lukito, Pergumulan Antara Hukum Islam dan Adat di Indonesia, Jakarta : INIS, 1998.

Samsul Hadi \& Abdurrahman, Perkembangan Ringkas Hukum Islam Di Indonesia Jakarta: Akademika Prasindo, 1984. 
Sajuti Thalib, Receptio a Contrario : Hubungan antara Hukum Adat dan Hukum Islam, Jakarta : Bina Aksara, 1985.

Sukarsi dari Ambtelijke Adviezen van C. Snouck Hurgronje, Snouck Hurgronje Semasa Kepegawaiannya kepada Pemerintah Hindia-Belanda 1889-1936, Jakarta : 1994.

Suparman Usman, Hukum Islam: Asas-Asas dan Pengantar Studi Hukum Islam dan Tata Hukum Indonesia, Jakarta : Gaya Media Pratama, 2001.

Supomo, Sejarah Politik Hukum Adat, Jakarta : Pranya Paramita, 1982.

Taufik Abdullah, "BPUPKI: Sebuah Episode di Panggung Sejarah", dalam Kompas, Sabtu, tanggal 1 Januari 2000.

Utrecht, Pengantar dalam Hukum Indonesia, Jakarta : Balai Buku Ikhtiar,1961.

Zainal Abidin Abu Bakar, Pengaruh Hukum Islam Dalam Sistem Hukum di Indonesia, dalam Jurnal dua Bulanan Mimbar Hukum, No. 9, Tahun IV 1993. 